\title{
Crecimiento sagital maxilar en fisurados unilaterales operados funcionalmente
}

\author{
Sagittal maxillary growth in unilateral cleft lip and palate patients following functional surgery
}

Todos conocemos la enorme variedad de técnicas y protocolos quirúrgicos para el tratamiento de la fisura labiopalatina congénita. Y seguimos desconociendo cuál es la mejor técnica para obtener un mejor resultado estético y funcional y a la vez minimizar los efectos deletéreos de la misma sobre el crecimiento facial. Se están haciendo muchos esfuerzos por parte de muchas instituciones para evaluar de forma científica estos protocolos, comparándolos entre sí, para obtener una respuesta.

Investigar sobre el efecto deletéreo de la cirugía sobre el crecimiento maxilar se torna ya controvertido desde el momento en que no sabemos todavía qué variables influyen en el hipodesarrollo del maxilar en estos pacientes. La misma técnica empleada por el mismo cirujano en deformidades similares a veces produce un resultado bien distinto. Cualquier publicación en este sentido cobra relevancia por sí misma, por eso es interesante comentar esta publicación al respecto. Sin embargo, hemos de señalar varias consideraciones sobre la misma.

Algunos errores metodológicos han podido observarse en el sentido de que no se determina cómo se ha hecho la selección aleatoria de los pacientes ni se informa de cómo se ha realizado la randomización de los casos. Resulta llamativo el pequeño número de pacientes en la muestra, y no sabemos el tamaño de la serie completa de pacientes. Así mismo, en el estudio no se especifica qué técnica de palatoplastia se ha realizado, tan solo se refiere que no se emplea mucosa vomeriana en la misma. Tampoco se señala si se ha realizado alveoloplastia ni la técnica empleada.

Los resultados muestran un crecimiento facial similar en ambos grupos, aunque a la edad en que se ha realizado el estudio cefalométrico, no va a predecir una hipoplasia maxilar futura. Por otra parte el problema de este estudio es la comparación con otros estudios, ya que el método utilizado no es el habitual en otros centros hospitalarios.1,2 La línea C1-F1 utilizada en este análisis cefalométrico para comparar el crecimiento facial, no es utilizada en otras comparaciones en la literatura. Esto dificulta la comparación inter-grupos, muy necesaria en este tipo de estudios. Por otra parte, la línea F1, al pasar por el eje del canino (agujero nasopalatino), no aporta información sobre el crecimiento del área premaxilar, que usualmente está afectado en los pacientes fisurados.

En un estudio realizado por Semb y Shaw, ${ }^{3}$ en relación con los problemas metodológicos encontrados en estudios comparativos sobre crecimiento facial en fisurados, se resalta la importancia de los estudios intercentros y la necesidad de realizar ensayos randomizados con casos control para testar la eficacia de las intervenciones.
Results of the multidisciplinary management of unilateral cleft lips and palates

Cleft lip and palate treatment has evolved over the centuries, and it has become increasingly complex, as objectives that are higher every time are sought, with the perfection of surgical techniques and the creation of multidisciplinary teams that treat all the facets of this type of pathology, from birth until adulthood.

The different specialists involved have to be in contact from the moment of birth, juxtaposing their actions over time, as the results obtained by each of the professionals in the team can even lead to modifications in the procedure protocol.

As from the moment of birth, the assistance will be needed of an orthodontist for carrying out presurgical treatment that is aimed at aligning the alveolar arcades in order to facilitate the closure of the anterior part of the cleft and the reconstruction of the nasal floor. The point at which the lip and palate are closed, as well as the surgical technique employed, have also been shown to be determining factors when trying to obtain more positive results, that are aesthetic as well as functional.

The assistance of a speech therapist is started in early infancy, in order to use the mechanisms for phonetic compensation adequately. This treatment is continued until adolescence, as the atrophy of adenoid tissue during puberty will require phonation evaluation. The degree of velopharyngeal incompetence may be indicative of the need for carrying out complementary surgical techniques on the soft palate, or closure of oronasal fistulas. The assistance of the orthodontist will continue to be fundamental during this time, in order to control the appearance of maxillary compression because of the inclination of the maxillary segment with the cleft, before as well as after the secondary alveoloplasty, and even further on, in order to maintain adequate coordination of the arcades, and for carrying out possible preorthognatic orthodontic treatment because of hypoplasia or maxillary retrusion.

The aim of the article is to convey the results obtained following the multidisciplinary treatment of patients with cleft lips and palates, but the objective is not met, as only the aesthetic results of cleft repairs are presented, in a hotchpotch manner and with contradictions in the statistical data.

In the Material and Methods section, there is a reference to an orthodontic evaluation by means of cephalometric studies, with the use of parameters that include only the 
Concluyendo, el estudio evalúa un protocolo quirúrgico de gran relevancia clínica, lo que aumenta su interés. Aunque observamos lagunas metodológicas en el estudio, por otra parte frecuentes en esta patología por razones obvias, aconsejamos a los autores continuar el estudio ampliando la muestra y añadiendo otros parámetros cefalométricos y clínicos que lo hagan susceptible de comparación con otros protocolos. Sin duda, siguen siendo necesarios estudios randomizados multicéntricos para evaluar la influencia de la cirugía en el crecimiento facial.

\section{Bibliografía}

1. Friede H, Enemark H, Sem G, Paulin G, Abyholm F, Boluund S, Lilja J, Östrup L. Craniofacial and occlusal characteristics in unilateral cleft lip and palate patients from four Scandinavian centres. Scand J Plast Reconstr hand Surg 1991;25:26976.

2. Sánchez-Ruiz Fernández I. Estudio evolutivo de la palatoplastia en dos tiempos en fisuras labiopalatinas completas. Tesis doctoral. Universidad del País Vasco, 1996.

3. Semb G, Shaw W. Facial growth alter different methods of surgical intervention in patients with cleft lip and palate. Acta Odontol Scand 1998;56:352-5.

José Luis López-Cedrún

Servicio de Cirugía Oral y Maxilofacial Complejo Hospitalario Juan Canalejo, La Coruña, España position of the upper and lower maxilla. The possible secondary disturbance from palate compression, which is so frequent in these patients, is not taken into account. And, in addition, there is no reference to the findings made, or to the planning or to the results. With regard to the evaluation of the speech therapy there is more of the same.

The article could be interpreted as a presentation of the accumulated experience of the authors, but no conclusions can be drawn given the variety of techniques used, and it cannot in any way be concluded that they have expanded on the title chosen. 